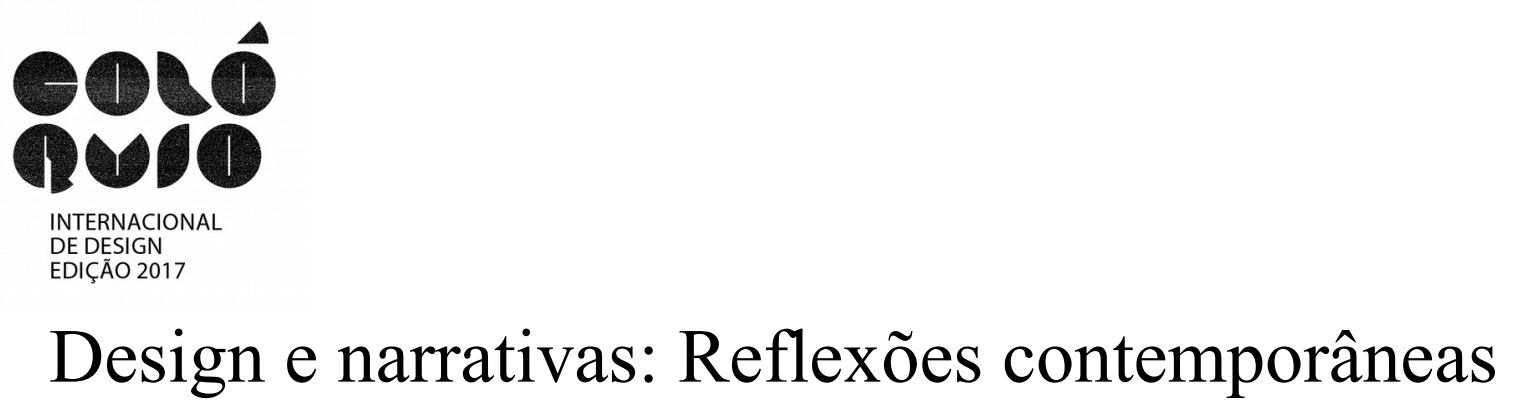

Marcos Maia;

resumo:

O presente artigo faz reflexões acerca das relações entre o design e as narrativas, buscando encontrar pontos de similaridade metodológica ou conceitual nos vários autores aqui citados. Nossa proposta é propor reflexões a partir da aproximação do design por um viés contemporâneo das teorias e práticas narrativas, percorrendo por conceitos e teorias como semiótica, narratologia, mito, consumo, psicologia, realidades narrativizadas, design interativo, ficção especulativa, design de narrativas, design estratégico, visando trazer alguns caminhos que possibilitam novas pesquisas e reflexões acerca do design. Tendo em vista a noção de design enquanto linguagem, podemos tentar abordar o potencial narrativo do design e diferentes campos do estudo que fazem essa aproximação, Embora o pensamento cartesiano tenha influenciado nosso pensar e fazer, ainda somos seres que se comunica por meio de histórias, desde o pensamento mitológico que visava explicar os fenômenos do mundo e a nós mesmos até os dias de hoje, evoluindo suas estratégias, perpassando as organizações sociais e políticas, as formas de comunicação e utilizando a evolução tecnológica, emergindo entre variados suportes até as narrativas transmidiáticas. De única forma de verdade e percepção do real, as formas narrativas foram descreditadas frente ao pensamento científico, e o mito virou sinônimo de mentira, passando novamente a ser consideradas as portadores dos aspectos culturais e hoje podemos rever a utilização dos elementos narrativos como forma de alteração da realidade. É no potencial das narrativas, de mobilizarem a crença, que reside a força das narrativas, onde o pensamento científico não alcança com a mesma capacidade de adesão. Tal como a verbal e imagética, o design é linguagem que materializa signos e conceitos em artefatos, e como as demais formas de comunicação poderia utilizar-se dos elementos narrativos para construir seu discurso aproveitando as possibilidades que trazem as narrativas que perpassam e constroem o mundo. Somos uma espécie movida por histórias e esse aspecto estruturante da nossa cognição pedem um esforço interdisciplinar para a construção de uma metodologia e epistemologia ainda pouco desenvolvida no design.

palavras-chave:

Design; Narrativas; Reflexões; Mito; Comunicação 


\section{Design e narrativas: Reflexões contemporâneas}

Quais são as possíveis intersecções entre os estudos narrativos e os estudos de design? Podemos pensar no design da narrativa, ou nas narrativas do Design? Que outras abordagens são possíveis quando investigamos apontamentos teóricos que permitem essa aproximação?

Para Sudjic (2010, p.34) o design não se baseia mais em modelos mecânicos. Para o autor, resta ao designer "a superfície, a aparência e as nuances semânticas do significado que nos permitem interpretar o que um objeto está tentando nos dizer sobre si mesmo [...] transformam o designer em um narrador". O autor faz a primeira aproximação já estabelecendo vários pontos que podemos investigar: "semântica do significado" "objeto fala sobre si" e "designer como narrador". O autor completa atribuindo a responsabilidade da eficácia a uma boa história, quando diz que "sem dúvida seja verdade que o design é uma linguagem, só quem tem uma história convincente para contar sabe como usar essa linguagem de maneira fluente e eficaz".

Antes de aproximarmos Design e Narrativas precisamos estabelecer, então, essas categorias ou estruturas que permitam essa aproximação. Partindo das pistas deixadas por Sudjic (2010) das possíveis relações do design com a narrativa, consideramos a história do conceito de narrativas, onde encontramos referência aos enunciados narrativos e suas preposições, categorias de interesse dos estudos de linguagem. Narrativas são desenvolvidas por sujeitos num contexto comunicacional.

Adam (1985, p.37) define a proposição narrativa como uma combinação de uma ou mais funções com um ou mais atores. "Uma proposição narrativa se apresenta como um predicado relacionado a 'n' argumentos-papéis narrativos".

Utilizando como substrato a teoria semiótica, Romanini $(2008$, p. 3) também trata o produto do trabalho do designer como uma proposição, quando diz que:

"no processo interpretativo, visto sob o prisma do usuário, é o produto criado pelo designer que se posiciona como signo-mensagem capaz de representar o conceito incorporado no produto e gerar, nesse usuário, um efeito. É nesse sentido que um produto de design equivale a uma proposição" (ROMANINI, 2008).

Já temos um primeiro indício da aproximação do design das categorias trabalhadas na narrativa. Para entender possíveis relações do estado da arte do Design e das Narrativas precisamos entender a conceituação de Design contemporaneamente. Diversos outros autores nos permitem pensar o design como linguagem conforme explicam, utilizando como entendimento para essa relação sua manifestação como produção cultural, além de atentarem para utilidade dos "estudos das linguagens para o campo do design, principalmente quando se trata dos seus aspectos comunicativos e de produção de significados" (BRAIDA e NOJIMA, 2016, p.43).

\subsection{Design como comunicação}

O trabalho do designer é análogo ao do comunicador (ROMANINI, 2008, p.3). O autor atenta para a visão de que uma proposição só possa assumir a forma de símbolos, como palavras de uma língua. Essa visão excluiria o Design do escopo dos estudos comunicacionais. O conceito é o tradicional de proposição. Quando surge a semiótica de Peirce, esses limites são ampliados, pois a semiótica traz a ideia de que muito mais do que "conceitos travestidos de símbolos".

Para o autor, o produto do design também guarda sempre uma gama de possibilidades interpretativas por parte do intérprete, que pode, inclusive, ressignificar com alguma liberdade, podendo obter alguns novos usos e interpretações, inclusive gerando novas proposições.

Desta forma, poderíamos perceber o designer como um emissor, no processo comunicativo, fazendo uma sintaxe entre a forma que elaborou e a materialidade que tem à sua disposição para então comunicar suas ideias, produzindo proposições que podem criar efeitos na mente do intérpretereceptor (ROMANINI, 2008).

Se percebermos os designers como produtores de proposições, para além das definições de solucionador de um problema específico, podemos ampliar as possibilidades de criação do designer 
enquanto comunicador, muito além da mobilização de significados para atender as necessidades de utilidade, ou mesmo de geração de valor, é possível transmitir muito mais informações.

Cardoso (2013, p.141) considera que "o que importa, em termos de design, é que a capacidade das formas de comunicar informações à mente humana é muito mais profunda e abrangente do que 'simplesmente' o conjunto de significados impostos pela sequência fabricação, distribuição e consumo".

Se falamos em intérprete-receptor, não podemos esquecer que ainda se trata de um consumidor. O próprio conceito de consumo é contemporâneo e alinhavado ao conceito que estamos utilizando para a atribuição de significados aos produtos do design. Pois não são os objetos materiais que são consumidos, pois são apenas objeto de necessidade e de satisfação. "Para tornar-se objeto de consumo o objeto precisa se tornar um signo" (BAUDRILLARD, 2006, p.207). O autor explica que:

"exterior de alguma forma a uma relação da qual apenas significa - 'portanto arbitrário' e não coerente com esta relação concreta, mas adquirindo coerência e consequentemente sentido em uma relação abstrata e sistemática com todos os outros objetos-signos. É então que ele se "personaliza", que entra na série, etc.: é consumido jamais na sua materialidade mas na sua diferença (BAUDRILLARD, 2006, p.207).

Para Baudrillard (2006), o consumo não se trata de uma prática material, portanto, não se trata da alimentação, vestuário, posse de veículos, ou mesmo a substância (verbal e não verbal) das imagens e mensagens, mas por tudo enquanto substância significante. O consumo seria, então, a "totalidade virtual" de todos os objetos e mensagens constituídos em um discurso cada vez mais coerente.

Como se trata de ter coerência, ou seja, possuir um sentido, se trata de "uma atividade de manipulação de signos" (BAUDRILLARD, p. 206).

Essa manipulação pode ser positiva ou negativa, mas ela pode ser exercita pelo designer, assim como pelo comunicador. Conforme Sudjic (2010, p.49) o design "pode ser usado de formas manipuladoras e mal-intencionadas, ou criativas e ponderadas. $\mathrm{O}$ design é a linguagem que ajuda a definir, ou talvez a sinalizar, valor". É uma linguagem que a sociedade se vale para criar objetos que reflitam seus valores e objetivos.

Esta mesma linguagem do design também será utilizada para sugerir diversas características do próprio objeto como o gênero, podendo ser com uso da cor, forma, tamanho ou referências visuais diversas, pois, conforme Sudjic (2010, p.21) "o design passou a ser a linguagem com que se molda esses objetos e confecciona as mensagens que eles carregam". O autor explica que "o design é usado para moldar percepções de como os objetos devem ser compreendidos. As vezes, é uma questão de comunicação direta [...] às vezes, a comunicação é mais emocional" (SUDJIC, 2010, p.51).

BRAIDA e NOJIMA (2016) lembram de alguns autores como Burdek (2006, p.283) que atenta para os primeiros estudos a considerar o design como fenômeno de linguagem, considera sua função comunicativa, e Moura (2003, p.102) que afirma ser o design uma linguagem, pois design está inserido na cultura, tal como atua com ela.

Essas ideias vêm sendo trabalhadas pelos teóricos do design desde a década de 70 , e continuam sendo aprimoradas.

Para Sudjic (2010, p.51) o design "é uma linguagem que evolui e modifica seus significados tão depressa como qualquer outra. Pode ser manipulada com sutileza e inteligência, ou com obviedade canhestra. Mas a chave para entender o mundo feito pelo homem".

Para o autor, o papel dos designers mais sofisticados, hoje, tanto é ser contadores de histórias, fazer um design que fale de uma forma que transmita essas mensagens, quanto resolver problemas formais e funcionais. (SUDJIC, 2010, p..21) 


\subsection{0 design do mito}

No capítulo sobre os objetos antigos, Baudrillard (2006) fala do fenômeno do interesse pelos objetos antigos e do valor simbólico dos objetos antigos. Diz que para o homem se sentir em casa, precisa utilizar objetos antigos como reorganizadores do mundo, o que o objeto funcional não consegue fazer. Enquanto o objeto funcional se esgota na cotidianidade, o objeto antigo surge como uma dimensão regressiva que testemunha um fracasso relativo do sistema, mas paradoxalmente, o faz funcionar. A ambiguidade deve-se à densidade inconsciente do objeto antigo que atua como um talismã que guarda a sabedoria dos anciãos.

Ao passo que objetos não dependem da ambiência, não serve pra nada, serve profundamente para qualquer outro.

"de onde surge essa motivação tenaz para o antigo, o velho móvel, o autêntico, o objeto de estilo, o rústico, o artesanal, o feito à mão, a cerâmica indígena, o folclore etc.? De onde surge esta espécie de fenômeno de aculturação que arrasta os civilizados para os signos excêntricos, no tempo e no espaço, do seu próprio sistema cultural, para os signos que arrasta os subdesenvolvidos para os produtos industriais?" (BAUDRILLARD, 2006, p.83).

A exigência à qual os objetos antigos respondem é de ser um ser definitivo. Para Baudrillard (2006, p.83) "o tempo do objeto mitológico é o perfeito" pois ele ocorre no presente como se tivesse ocorrido outrora por este motivo acha-se fundado sobre si, "autêntico". O objeto antigo é sempre, no sentido exato do termo, um "retrato de família".

Sob a forma concreta do objeto a imemorização de um ser precedente existe - processo equivale, na ordem imaginária, a uma elisão do tempo. É o que falta aos objetos funcionais, que existem somente na atualidade, se esgotando em seu próprio uso, se assegurando no espaço, mas não no tempo.

Baudrillard (2006) vai responder sua própria pergunta do porquê do interesse pelos objetos antigos, dizendo que "o objeto funcional é eficaz, o mitológico, perfeito". O autor completa que "O objeto antigo dá-se, portanto como mito de origem".

Quando falamos em mito, estamos falando na historicidade do objeto, isto é, uma narrativa que o objeto foi adquirindo com o passar do tempo, sua própria história no percurso do tempo.

Falar em mito é falar em narrativa. Narrar é uma ação que acompanha a humanidade há séculos, desde o surgimento do pensamento mítico visando explicar o próprio homem, o mundo e seus fenômenos.

Temos os registros arqueológicos materiais com arte rupestre que contam-nos narrativas de outra era, e hoje, "as histórias de fadas, contos, piadas, novelas, cinema e tantos outros, passando também pelos mitos e livros sagrados - todos expressam e são alcançados pelas narrativas em vários suportes" (GANCHO, 2006).

Conforme explica Hoad (2003), o conceito de narrar, remete ao termo narrare, derivado, por sua vez, do termo latino gnarus, que significa "saber", "conhecer algo" (a palavra oposta, ignarus, com a adição do prefixo i, formou o adjetivo 'ignorante').

Teixeira (2015) explica que o termo denota a partilha de conhecimento, o contar e dizer, de modo que se pode entender que narrativa trata-se do próprio ato de contar uma história, enquanto a narração se refere ao conteúdo deste ato. Uma história é um agrupamento de situações narradas, enquanto que a forma como essa história é narrada chama-se enredo.

A narrativa é, portanto, composta por enredo, história e narração, conforme Nogueira (2010). Barthes (1975) nos lembra que as formas de narração existentes são diversas e imensuráveis, pois há uma variedade de gêneros que se distribuem por tantas mídias quanto possíveis, sugerindo que todas as substâncias podem ser "invocadas" para dar conta das histórias (BARTHES, 1975, p. 237).

O estudo da narrativa tem na obra "Poética" de Aristóteles (1992), uma base de referência que foi escrita em meados de 335 a.C. e continua válida até hoje devido à profundidade de sua análise. Posteriormente Propp (1983) propõe-se a analisar a morfologia dos contos de fada, descrevendo os contos por suas partes constitutivas relacionando-as entre si. 
O autor Bremond (1966) faz uma revisão dos estudos elaborador por Propp, expandindo-os para além dos contos de fada, tratando das narrativas no geral e elabora um modelo de "estrutura dos enunciados narrativos".

Visando estabelecer uma estrutural fundamental, Greimas (1973), sistematiza quatro etapas formadoras da narrativa: o contrato, a competência, a performance e a sanção, formando um ciclo que para ele, são os elementos que compõem a narrativa.

Podemos perceber que temos o estabelecimento de algumas bases como: considerando o enunciado que atende alguns pressupostos como narrativo, por uma visão estruturalista. Para uma narrativa coerente é necessário que as proposições estejam relacionadas de forma cronológica e lógica.

Já Goodman (1981), atenta que a simples ordenação de eventos em categorias estéticas ou científicas transforma uma estória em estudo, destituindo seu caráter narrativo. A representação temporal dos eventos ainda é um elemento-chave para a compreensão da narrativa, mesmo que essa ordem não precise seguir uma sequência inflexível. A não cronologia da ordem não destitui o caráter narrativo.

O autor Ricoeur (1994) vai considerar a narrativa como a representação mais clara e exata do tempo, como um caráter temporal da existência do homem. Para tal, parte das ideias de Santo Agostinho (1987) que afirma só se poder definir e medir o tempo a partir do interior do homem, pois o pontífice considera a natureza do tempo como sendo psicológica.

Jung (1984) em seus estudos também chegou a percepção de uma "estrutura no enunciado narrativo" que vai chamar de drama, remontando à Aristóteles (1922) como outros autores já que Aristóteles continua sendo uma referência para os estudos de narrativas, que ele vai chamar de drama. Para Jung (1984) estrutura narrativa se organiza com quatro macroproposições: exposição, desenvolvimento, peripécia e resultado, obtidas a partir da análise dos sonhos.

Os sonhos são fonte profícua para obter respostas sobre nossa própria origem e nosso futuro. Sua relação com o pensamento mitológico é inegável e relacionado aos arquétipos que nos remetem ao pensamento mítico.

As religiões, filosofias, artes, formas sociais do homem primitivo e histórico, descobertas fundamentais da ciência e da tecnologia e os próprios sonhos que nos povoam o sono surgem do círculo básico e mágico do mito.

$\mathrm{O}$ prodígio reside no fato de a eficácia característica, no sentido de tocar e inspirar profundos centros criativos, estar manifesta no mais despretensioso conto de fadas narrado para fazer a criança dormir — da mesma forma como o sabor do oceano se manifesta numa gota ou todo o mistério da vida num ovo de pulga. Pois os símbolos da mitologia não são fabricados; não podem ser ordenados, inventados ou permanentemente suprimidos. Esses símbolos são produções espontâneas da psique e cada um deles traz em si, intacto, o poder criador de sua fonte.

Qual o segredo dessa visão intemporal? De que camada profunda vem ela? Por que é a mitologia, em todos os lugares, a mesma, sob a variedade dos costumes? E o que ensina essa visão? (CAMPBELL, 1995)

Conforme Jung (2000, p.9), os arquétipos "não são disseminados apenas pela tradição, idioma ou migração. Eles podem reaparecer espontaneamente a qualquer hora, em qualquer lugar, e sem qualquer influência externa”. Os arquétipos são modelos universais, predisposições e tendência a experimentar as coisas de determinadas formas. São importantes elementos da psique humana que podem ser encontrados em todos os povos, civilizações, em qualquer era, independente do tempo.

O pensamento mítico é a primeira forma que os homens desenvolvem para responder às suas questões existenciais. São narrativas de deuses, heróis e jornadas para ilustrar e explicar os diversos fenômenos, o mundo e o próprio comportamento humano, além de transmitir valores e a própria cultura. Os mitos surgem com o pensamento mítico e são formas de expressão dos arquétipos.

Por ser parte de uma tradição cultural, o mito configura assim a própria visão de mundo dos indivíduos, a sua maneira mesmo de vivência esta realidade. Nesse sentido, o pensamento mítico pressupõe a adesão, aceitação dos individuas, na medida em que constitui as formas de sua experiência do real (MARCONDES, 2002, p20). 
Com o surgimento da filosofia que busca uma forma lógica de pensar, e posteriormente a ciência, mito torna-se um conceito pejorativo, usado para expressar mentira.

No entanto, as narrativas seguindo o modelo mítico e usando os arquétipos está presente em diversas áreas da sociedade contemporânea: desde as narrativas jornalísticas aos discursos políticos e das instituições que estruturam e organizam a sociedade da forma que conhecemos. Além de estar artisticamente representada como forma de entretenimento ou forma de transmissão de conhecimento, tanto na educação como na arte, em diferentes formatos e suportes: teatro, cinema, quadrinhos, literatura etc., contando com toda evolução tecnológica.

Mentiras disseminadas nas redes sociais podem mobilizar um grupo grande de pessoas e alterar a realidade física a partir das ações de grupo. Os boatos disseminados intencionalmente utilizam dessa força que a forma de contar histórias possui, mobilizando um contingente de pessoas movido mais pelas narrativas que pelos fatos objetivos. Mesmo um filme, série ou novela podem mudar comportamentos e visões acerca de um assunto. As autoras Ângela Marques e Rousiley Maia (2008, p.165-206) mostram como as telenovelas A Próxima Vítima (Globo, 1995) e Torre de Babel (Globo, 1998/99) que se utilizaram de narrativas de sujeitos homoafetivos que desafiam discursos dominantes da época provocando uma série de argumentações diversas em outros meios de comunicação sobre as questões envolta das pessoas gays e lésbicas: direitos, estilo de vida e demais aspectos relacionados a esta orientação afetivossexual, promovendo a deliberação no espaço público.

Essa tendência narrativa pode ter explicações do campo da psicologia. O autor Bruner (2001) vai além e considera as narrativas um modelo de pensamento. $\mathrm{O}$ autor teoriza que a interação do homem com o mundo acontece dialeticamente e para criar essa relação entre "mundo interno" (mente) e "mundo externo" (extracorpóreo, perceptível aos sentidos) utiliza como estratégia o pensamento narrativo e científico. Os dois modos de funcionamento cognitivo constroem realidades, ordenando a experiência cada um da sua forma, construindo realidades.

As realidades narrativizadas, eu suspeito, são demasiadamente onipresentes, sua construção é demasiadamente habitual ou automática para ser acessível à fácil inspeção. Vivemos em um mar de histórias, e como os peixes que (de acordo com o provérbio) são os últimos a enxergar a água, temos nossas próprias dificuldades em compreender o que significa nadar em histórias.

Não que não tenhamos competência em criar nossos relatos narrativos da realidade longe disso -, somos, isso sim, demasiadamente versados. Nosso problema, ao contrário, é atingir uma consciência do que fazemos facilmente de forma tão automática, o antigo problema da prise de conscience (BRUNER, 2001, p.140).

A estrutura do pensamento narrativo concorda com gêneros do discurso internalizados, de forma que é difícil distinguir bem o pensamento do texto narrativo pois o pensamento torna-se inextrincável da linguagem que o expressa. $\mathrm{O}$ que nos permite refletir se um produto do design comparado a uma proposição a ser interpretada também pode ser pensado na sua produção tendo em vista o modelo cognitivo narrativo.

Joseph Campbell uma das definições mais belas - quase poética - de mitologia: “A mitologia é a canção do universo - música que nós dançamos mesmo quando não somos capazes de reconhecer a melodia" (1990, p. XI).

Tal como Bruner, Campbell sugere que fazemos intuitivamente algumas coisas, corroborando para uma visão de um pensamento narrativo, ou seja, mitológico, ainda que Campbell esteja se referindo aos arquétipos. Poderiam ser os arquétipos a forma mais visível no atual estado da arte sobre o estudo das narrativas por esta abordagem.

Nicola Abbagnano (2000) agrupa diversos conceitos de autores e chega a três visões do mito: A primeira como contrária ao Lógos, à Razão e ao discurso filosófico, numa visão histórica linear; a segunda entendendo o mito como "uma forma autônoma de pensamento ou de vida" (p.673) podendo ser relacionada às ideias de Bruner (2001); e, por último, considera o mito com a função única de dar continuidade à cultura [...] não apenas ligando-o às sociedades antigas, mas indispensável para qualquer cultura, sugerindo "estudá-lo em relação à função que exerce na sociedade humana" (p.675), 
permitindo-nos perceber as narrativas como partes constituintes das culturas humanas ao passo que dentre outras funções, às promove e perpetua.

\subsection{Design de ficção}

A tendência narrativa do homem nos leva a desenvolver diferentes formas de contar histórias. Além de nos apropriarmos das diversas tecnologias para contar essas histórias.

Para Sutton (1997) toda nova linguagem é poética e metafórica num primeiro momento. Uma nova imagem permite a possibilidade de significar algo, para poder submetê-la ao juízo e à crítica e à comprovação experimental. Para o autor, toda nova linguagem começa interpretativa tentando comparar e compartilhar interpretações para chegar a acordos sobre como percebemos as coisas (p.18).

Sutton (1997) se refere a novos paradigmas para o ensino de ciências. Mas o mesmo ocorre em diversas esferas da vida cotidiana, em que trabalha-se de forma lúdica, isto é, com recursos narrativos para abordar os temas. As novas tecnologias permitem ao homem outros canais e recursos para essa comunicação.

Como campo para desenvolvimento de discursos narrativos, além das mídias como jogos, quadrinhos, literatura, teatro e outras que podem ser utilizadas pelo design, podemos destacar o próprio design como canal para esses discursos narrativos quando falamos de design interativo e design especulativo.

PAPANEK (1993) considera que "um designer, no sentido mais lato do termo, é um ser humano que percorre com êxito a estreita ponte que liga aquilo que nos foi deixado pelo passado às possibilidades futuras"(p.215).

O Autor Heinlein (1947) cunhou o termo "ficção especulativa" (reduzido para spec-fi) sugerindo que as ficções não precisariam utilizar somente a ciência como base. Ele sugere que o processo pode ser mais amplo e variar.

Para Jones (2015) todo design é ficção até certo ponto, antes de se concretizar. Quando se projeta para um futuro ou mundo novos, entender os detalhes desse mundo em que pensamos, torna-o mais crível. Por conter, nessa elaboração ficcional, especulações e mobilizar símbolos em intenções, o design traz consigo princípios de narratividade.

Já Sterling (2009) pondera que o processo criativo pode ser propositivo em relação a inovações tecnológicas, demonstrando que a diégese de obras midiáticas podem se apropriar das metodologias do design. As interfaces do dia a dia possuem semelhanças com as ficções especulativas, pela possibilidade de transformação ou mesmo a ubiquidade da internet das coisas, especialmente a noção diegética do tempo, uma narrativa de cada interação nas interfaces digitais e artefatos.

A fragmentação da comunicação nos diversos suportes permitem uma dinâmica assíncrona em que o tempo e lugar do emissor não são tão relevantes, o que Baudrillard (1983) chama de hiperrealidade. Os espaços virtuais e materiais se misturam criando um espaço de narrativa verossímil.

A ficção especulativa é responsável por muitos produtos interativos como por exemplo, no filme Minority Report (2002) em que aparece uma tecnologia de interface gestual, se tornando uma referência do imaginário coletivo, por meio de uma narrativa. Outras obras como Star Trek (1960) que previu ou sugeriu as tecnologias de comunicação móveis como celular, ou 007 Goldfinger (1964) que anteviu o GPS.

Tal como na arte, o design tem em sua gênese a histórica necessidade do homem de se manifestar criativamente para solucionar problemas do mundo com inovações tecnológicas. Durante o processo de prototipagem do design, são elaborados cenários fictícios, personas, cria-se mundos virtualmente.

A interação narrativa-design, por este ponto de vista é relevante para entendermos que muitas soluções materializadas a partir de ficções antigas, outras possibilidades futuras para o design de interação são possíveis principalmente para as interfaces homem-máquina que ainda não são muito atraentes, precisam ser humanizadas, narrativizadas. Pelas transformações sociais e tecnológicas precisamos entender melhor as relações entre design e ficção. 


\subsection{Design de Narrativas (de jogos)}

Dentre as diferentes interfaces homem-máquina podemos destacar as simulações virtuais e jogos narrativos como interfaces para experiências lúdicas que servem a tantos propósitos quanto possíveis.

Um jogo é um sistema onde os jogadores envolvem-se em um conflito artificial, definido por regras, que implica em um resultado quantificável (SALEN; ZIMMERMAN, 2012, p. 95). De outro lado, o design é uma atividade que configura objetos de uso e sistemas de informação visando materializar uma finalidade ideal Bomfim (1999). Essas duas definições destacam semelhanças enquanto sistemas que podem ser relacionados.

Fica claro, se consideramos que o jogo é um projeto que respeita os mesmos pressupostos do design, sendo possível aplicar a mesma lógica para identificar a existência de desdobramentos narrativos em ambos, formando-se então, o design de narrativa Oliveira (2014).

Design de narrativa é a criação da história e das mecânicas pelas quais passará o jogo, compreendendo não só a história propriamente dita, mas também como ela será comunicada ao jogador, e também como outras funções do jogo farão o jogador imergir no mundo do jogo (POSEY, 2008, p.871).

Dentre os jogos que podem ser facilmente reconhecidos como narrativos, existem duas categorias principais: Os jogos de personagem com construção de um ambiente navegável cada vez mais sofisticado no qual a sensação de imersão e de "presença vicária" (Darley, 2002, p.237), cuja imersão se dá através do avatar do protagonista. A linguagem possui heranças do cinema com uso de narrativas clássicas. Já os jogos de simulação se afastam dessa narrativa clássica propondo uma experiência de controle de um sistema como se o jogador fosse um deus que controla aspectos do mundo criado. No entanto, existe uma tendência à hibridação das duas vertentes culminando num formato narrativo próprio.

Simulação é um "instrumento fundamental da significação", faz referência à "constituição de um modelo (hipótese teórica) interpretativo a respeito de uma certa realidade e, em segunda instância, à verificação empírica da funcionalidade e da adequação deste modelo" (BETTETINI,1989, p.71)

$\mathrm{O}$ design de narrativa é planejar a narrativa do jogo verificar se existe coerência entre a narrativa incorporada e a emergente (Oliveira 2013), o autor atenta que a história deve contextualizar e envolver o jogador, com uso de mecânicas que se relacionam com a história proposta.

Uma analogia possível com a função do designer de narrativas é em relação ao roteirista hipermídia devido à necessidade de formação interdisciplinar que precisa realizar as funções de um roteirista audiovisual Gosciola (2010), mas superando a linearidade das mídias narrativas como teatro e audiovisuais, considerando a experiência interativa do usuário.

Cardoso (2013), traz o entendimento de que o designer leva o jogador a cumprir um papel específico em um sistema que proporciona recompensas de forma coerente e incorporadas à narrativa, como forma de manter sua motivação. Se esse "pacto" entre o designer e o jogador for selado, a experiência do jogador se caracterizará como uma narrativa significante.

\subsection{Uma narrativa estratégica}

Os jogos permitem uma identificação mais direta dos efeitos que a simulação ou mesmo os jogos de personagem causam no jogador, "substituindo" a realidade material em que se encontram pela realidade criada, ou melhor, alterando a percepção da própria realidade. Mas toda forma de entretenimento como os quadrinhos, literatura, cinema, TV, teatro, entre outras, mesmo uma história contada verbalmente sem nenhum outro recurso senão a fala, consegue o efeito de transportar o intérprete-receptor para o mundo criado narrativamente, podendo alterar a percepção da realidade, sobrepô-la ou mudar conceitos acerca desta realidade.

Os Estudos Culturais com as teorias estéticas da recepção ativa (HALL) falam da capacidade de ressignificação dos objetos de consumo (CANCLINI, 1995). E é nesta possibilidade de permitir a ressignificação (ou alteração de elementos da realidade) que o design como teoria e prática mostra um grande potencial. 
Cardoso (2013, p.20) atenta a importância dos conceitos imateriais quando diz "Em uma palavra, o 'imaterial' passou a ser o fator decisivo em quase todos os domínios, mormente numa área como o design".

Essa transição dos conceitos trabalhados nas narrativas e trazidos para a materialidade nos levam a pensar sobre a transição que fazemos ao consumir uma narrativa de forma interativa com a realidade material. Para Cardoso (2013, p.40) "a possibilidade de realizar transições muito rápidas entre material e imaterial é um dos fenômenos mais marcantes da atualidade" (CARDOSO, 2013, p.40).

Não só os significados mobilizados no fazer do designer são capazes de gerar efeitos, mas também a disposição destes, no objeto ou com o objeto do designer geram efeitos de sentido e, portanto as narrativas que suscitam devem ser pensadas. Ainda, o objeto material ou imaterial do designer pode ser trabalhado dentro ou junto com narrativas, ampliando as possibilidades da práxis do design.

\section{Considerações Finais}

Desde o pensamento mítico, evoluindo para as narrativas transmídias contemporâneas, as narrativas passaram de verdade à mentira e, portadoras da cultura e dos valores humanos, são verdades relativas ao alterar as percepções da realidade.

"A capacidade de criar histórias que pudessem gerar uma lógica em torno de um evento, seja ele natural ou sobre alguma moral humana, rendeu ao mito a possibilidade do ser humano de conseguir imaginar o não objeto e crer nele como fato" (MERLEAU-PONTY, 1965).

É no potencial das narrativas de mobilizarem a crença que reside a força das narrativas, onde o pensamento científico não alcança com tamanha pregnância.

Somos uma espécie movida por estórias e essa motivação precisa ser consciente no design.

"Nosso apetite por estórias é um reflexo da necessidade profunda do ser humano em compreender os padrões do viver, não meramente como um exercício intelectual, mas como uma experiência pessoal e emocional. Nas palavras do dramaturgo Jean Anouilh, a ficção dá à vida sua forma” (MCKEE, 2006, p.25).

A visão contemporânea do design atenta para sua imaterialidade e sua relação enquanto proposição a ser interpretada, pois design é uma forma de comunicação e como linguagem tal como a verbal ou imagética buscar as possibilidades que trazem as narrativas que inundam e constroem nosso mundo.

Enquanto áreas de investigação teórica, o design interativo, o design especulativo e as relações entre design e ficção são profícuas, contendo uma série de novos termos numa taxonomia que vem se alterando conforme avançam os estudos.

$\mathrm{O}$ design de narrativa encontra nos jogos um maior aporte teórico, mas existe espaço e precisa de mais desenvolvimento dos estudos acerca desta e de outras categorias multimídias.

Estudos sobre a historicidade e narratividade dos objetos de design podem ser aprofundados, mas pedem um esforço interdisciplinar para a construção de uma metodologia e epistemologia ainda incipiente.

Como modelo cognitivo, o pensamento narrativo propõe reflexões acerca da forma de pensar e da prática do design que podem sugerir caminhos para uma criação mais ciente dos processos narrativos.

Evidente que as aproximações entre Design e Narrativas possuem muitos mais pontos de intersecção que os apresentados neste artigo. Entretanto, muitos caminhos aqui citados permitem vislumbrar o mar de possibilidades (narrativas) do qual fala Bruner (2001) e, cientes do potencial que traz o mito, incorporar aos estudos do design, num contexto mais que contemporâneo, atemporal. 


\section{Design and narratives: Contemporary reflections}

Abstract: The present article reflects on the relations between design and narratives, seeking to find points of methodological or conceptual similarity in the various authors mentioned here. Our proposal is to propose reflections from the approach of design through a contemporary bias of narrative theories and practices, through concepts and theories such as semiotics, narratology, myth, consumption, psychology, narrativized realities, interactive design, speculative fiction, narrative design, strategic design, aiming to bring some paths that make possible new researches and reflections about the design. Given the notion of design as language, we can try to address the narrative potential of design and different fields of study that make this approach. Although Cartesian thinking has influenced our thinking and doing, we are still beings who communicate through stories, from the mythological thought that aimed to explain the phenomena of the world and ourselves up to the present day, evolving their strategies, crossing the social and political organizations, the forms of communication and using technological evolution, emerging from various supports to the transmedia narratives. From the only form of truth and perception of the real, the narrative forms were skewed in the face of scientific thought, and the myth became a synonym of a lie, once again considered the bearers of cultural aspects and today we can review the use of narrative elements as a form of change of reality. It is in the potential of the narratives, to mobilize the belief, that lies the force of the narratives, where scientific thought does not reach with the same capacity of adhesion. Like verbal and visual, design is a language that materializes signs and concepts in artifacts, and like other forms of communication, one could use the narrative elements to construct their discourse, taking advantage of the possibilities that bring the narratives that permeate and construct the world. We are a species driven by stories and this structuring aspect of our cognition calls for an interdisciplinary effort for the construction of a methodology and epistemology still little developed in the design.

Keywords: Design; Narratives; Reflections; Myth; Communication

\section{Referências bibliográficas}

ABBAGNANO, Nicola. Dicionário de Filosofia. São Paulo: Martins Fontes, 2000

ADAM, J-M. Le texte narratif. Paris: Nathan, 1985

Aristóteteles. Poética (E. de Souza, Trad.). São Paulo: Ars Poética, 1992

BARTHES, Roland; DUISIT, Lionel. An Introduction to the Structural Analysis of Narrative. New Literary History. New York, v. 6, n. 2, 1975

BAUDRILLARD, Jean. Simulations. New York: Semiotext(e), 1983

BAUDRILLARD, Jean. 0 sistema dos objetos. [Tradução: Zulmira Ribeiro Tavares]. São Paulo: Perspectiva, 2006

BETTETINE, Gianfranco. Por un establecimiento semio-pragmático del concepto de simulación. Videoculturas de fin de siglo. Madrid: Cátedra, 1989

BOMFIM, Gustavo Amarante. Coordenadas cronológicas e cosmológicas como espaço das transformações formais. In: OLIVEIRA, Alfredo Jefferson de; COUTO, Rita Maria de Souza. Formas do design: por uma metodologia interdisciplinar. Rio de Janeiro: Pontifícia Universidade Católica do Rio de Janeiro - PUC/RJ, 1999

BRAIDA, Frederico; NOJIMA, Vera Lúcia. Por que Design é linguagem? 2.ed. Juiz de Fora, MG: FUNALFA: Ed. UFJF, 2016 
BREMOND, C. La logique des possibles narratifs. Communications, 1966

BRUNER, Jerome. A interpretação narrativa da realidade. Porto Alegre: Artmed, 2001

BURDEK, Bernhard E. História, teoria e prática do design de produtos. São Paulo: Edgard Blucher, 2006

CAMPBELL, J.; MOYERS, B. O poder do mito. São Paulo: Palas Athena, 1990

CANCLINI, Nestor. Consumidores e cidadãos. Rio de Janeiro, Ed. UFRJ, 1995

CARDOSO,Rafael. Design para um mundo complexo. São Paulo: Cosac Naify, 2013

DARLEY, Andrew. Genealogia y tradicion: el espetáculo mecanizado. In: Cultura visual digital. Espetáculo y nuevos géneros en los medios de comunicación. Barcelona: Paidós, 2002

GANCHO, Cândida Vilares. Como analisar narrativas. São Paulo: Ática, 2006

GOODMAN, N. Twisted tales; or, story, study and simphony. Em W. J. T. Mitchel (Org.), On narrative. Chicago: University of Chicago Press, 1981

GOSCIOLA, Vicente. Roteiro para as novas mídias - do cinema às mídias interativas. 3. ed. São Paulo: Editora Senac, 2010

GREIMAS, Algirdas Julien. Semântica estrutural. São Paulo: Cultrix, 1973

HOAD, T. F. The Concise Oxford Dictionary of English Etymology. Oxford University Press, 2003 Disponível em:

<http://www.oxfordreference.com/view/10.1093/acref/9780192830982.001.0001/acref-

9780192830982>. Acessado em 20/09/2017

HEINLEIN, R. A; Of Worlds Beyond. Saturday Evening Post, 1947

JONES, Matt. Interaction Symposium, 2015. <http://www.cooper.com/journal/2015/2/day-2interaction15>. Acessado em 20/09/17

JUNG, C. G. 0 inconsciente pessoal e o inconsciente coletivo. Petrópolis: Vozes, 1942

JUNG, C. G. Os Arquétipos e o Inconsciente Coletivo. Petrópolis: Vozes, 2000

MARCONDES, Danilo. Iniciação à História de Filosofia. Dos Pré-socráticos a Wittgensteisn. $7^{a}$ edição. Rio de Janeiro: Jorge Zahar, 2002

MARQUES, Angela, C.S.; MAIA, Rousiley C. M. Apelo emocional e mobilização para a deliberação: o vínculo homoerótico em telenovelas. In: MAIA, Rousiley C. M. (Org.) Mídia e deliberação. Rio de Janeiro: Editora FGV, 2008

MCKEE, R. Story: substancia, estrutura, estilo e os princípios da escrita de roteiro. Curitiba: Arte \& Letra, 2006

MERLEAU-PONTY, Maurice. Trans: Colin Smith. Phenomenology of Perception. London: Routledge \&Kegan Paul, 1965

MOURA, Mônica. O design de hipermídia. 2003. 375f. Tese (Doutorado em Comunicação e Semiótica) - Pontíficia Universidade Católica de São Paulo, São Paulo, 2003

NOGUEIRA, Luís. Manuais de Cinema I: laboratório de guionismo. Covilhã, LabCom Books, 2010 OLIVEIRA, Thaiane. A Arquitetura de uma narrativa transmidiática: análise do jogo de realidade alternada Zona Incerta. Mediação: Belo Horizonte, v. 15, n. 16, jan./jun., 2013

PAPANEK, V. "Renovar as coisas e torná-las belas", in CALÇADA, A. et AL (Coord.). Design em aberto. Uma antologia, Lisboa: Centro Português de Design, 1993

PROPP, V. Morfologia do conto (J. Ferreira \& V. Oliveira, Trads.). Lisboa:Veja, 1983

RICOEUR, P. Tempo e narrativa (C. M. César, Trad.). Campinas: Papirus, 1994

ROMANINI, V. Design como comunicação: uma abordagem semiótica. Design "Quo Vadis" FAU-USP, Ago. 2008. Disponível em: <https://goo.gl/fnVh1z>. Acessado em 20/09/2017 
SALEN, Katie; ZIMMERMAN, Eric. Regras do jogo: fundamentos do design de jogos - Vol. 3. São Paulo: Editora Blucher, 2012

Santo Agostinho (1987). Confissões (J. O. Santos \& A. A. de Pina, Trads.). São Paulo: Nova Cultural SUDJIC, D. A linguagem das coisas. Rio de Janeiro: Intrínseca, 2010

SUTTON, Clive. Ideas sobre la Ciencia e Ideas sobre el lenguage. in: Alambique Didactica de Las Ciencias Experimentales. n.12, 1997

STERLING. B. Design Fiction. ACM.ORG Interactions, 2009 